Çukurova Üniversitesi Mühendislik Mimarlık Fakültesi Dergisi, 30(1), 1-16 ss., Haziran 2015

Çukurova University Journal of the Faculty of Engineering and Architecture, 30(1), pp. 1-16, June 2015

\title{
Atık Demir Tozu Katkılı Harç ve Betonların Durabilite Özellikleri
}

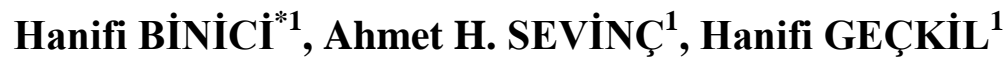 \\ ${ }^{1}$ Kahramanmaraş Sütçü İmam Üniversitesi, İnşaat Mühendisliği Bölümü, Kahramanmaraş \\ Geliş tarihi: 14.11.2014 \\ Kabul tarihi: 26.06.2015
}

\section{Özet}

$\mathrm{Bu}$ çalı̧̧mada; demir tozu içeren harçların ve betonların dayanım ve dayanıklılığı araştırılmıştır. Harç ve betonda kum yerine değişik yüzdelerde demir tozu kullanılmıştır. Harç numunelerin basınç ve eğilme dayanımı ile bazı mekanik özellikleri araştırılmıştır. Harç numunelerin sülfat ve tuza karşı dayanımları belirlenmiştir. Ayrıca ultrasonik ses geçirimi, aşınma dayanımı, kılcal su emme değerleri araştırılmıştır. Demir tozu katkılı harç ve betonların basınç, eğilme, aşınma ve sülfat etkisine karşı dayanımları kontrol örneğine göre daha yüksek bulunmuştur. Özellikle $\% 20$ demir tozu katkılı beton numunesinin basınç dayanımı $\% 50$ oranında daha fazla bulunmuştur.

Anahtar kelimeler: Atık demir tozu, Harç, Beton, Durabilite

\section{Durability Properties of Mortars and Concretes with Waste Iron Powder}

\begin{abstract}
In this study, the strength and durability of mortar and concrete containing an iron powder was investigated. In different percentages of iron powder instead of sand mortar and concrete were used. Compressive and flexural strength of samples of and such mechanical properties were investigated. Sulfate resistance of mortars were determined. Also the ultrasonic sound penetration, wear resistance, capillary absorption values were investigated. Compressive, bending, abrasion and sulphate resistance of mortar and concrete made with iron powder were higher than the control sample. Especially compressive strength of samples made with $20 \%$ waste powder iron was higher by $50 \%$ than those of control samples.
\end{abstract}

Keywords: Waste iron powder, Mortar, Concrete, Durability

\footnotetext{
* Yazışmaların yapılacağı yazar: Hanifi BíNici, Kahramanmaraş Sütçü İmam Üniversitesi, Inşsaat Mühendisliği Bölümü, Kahramanmaraş. hbinici@ksu.edu.tr
} 


\section{GİRIŞ}

Dünya nüfusundaki artış, yapılaşma ve endüstrinin büyümesi neticesinde, doğal kaynakları tehdit eden kirlenmeler, insanlığın önemli sorunlarından biri olmuştur. Dünya ekolojik dengesinin korunması, öncelikle bu sorunların bilinmesi ve tanınmasından geçmektedir [1-2].

$\mathrm{Bu}$ amaçla, ekolojik denge üzerinde önemli bir sorun oluşturan endüstriyel atıkların geri dönüşümü üzerinde, bir çok sektörde olduğu gibi yapı sektöründe de bilimsel araştırmalar yapılmaya devam etmektedir.

Sürdürülebilir temel amaçlarından biri geri dönüşüm ve atık yönetiminin yeniden kullanımını maksimize etmektir. Geri dönüşüm depolama için uygun olmayan malzemeler için mantıklı bir seçenektir. Metal, plastik ve cam bu malzemelerin en yaygın olanlarındandır [3]. Demir ve çelik sanayi atıkları endüstriyel katı atıkların ana kaynaklarından önemli bileşenlerinden birini temsil demir ve çelik üretim tesisleri, yanı sıra küçük ve orta ölçekli atölyeler de muhtemeldir Çalışmada, atık demir ile yapılan beton karışımların geleneksel betona göre yüksek basınç ve eğilme dayanımı göstermiş olduğu belirtilmektedir [4]. Geri dönüşüm, atıkların doğaya atılmasının ve düşük maliyet ve enerji tasarruflu ürünlerin geliştirilmesi için önemli hacimlerde uzun vadeli firsatlar sunar [5]. Granül cüruf ve çelik cips, demir ve çelik sektöründe endüstriyel atık ve düzgün değerlendirilemediği zaman insan sağlığına ve çevreye olumsuz etkilerde bulunmasına neden olur. Temel amaç katı atık bertaraf sorununu mümkün olduğunca malzemelerin geri kazanımı ile hammadde kullanımın azaltılması üzerine odaklandırmaktır. Yapılan çalışmada atık demir etkisi beton özellikleri üzerindeki etkisini araştırılmıș ve geleneksel betona göre üstünlükleri belirlenmiştir [6].

Beton karışımları düşük $\mathrm{CaO}$ işlenmemiş çelik cüruf kullanımı ile ilgili çelik cürufu (\%30 kadar) düşük kum oranları için kullanıldığında betonun derecesine bağlı olarak, basınç dayanımı iyileştirilmiş olduğunu göstermiştir [7]. Endüstriyel demir talaşı atığının taze betonun işlenebilirliğini ve taze ve sertleşmiş beton numunelerin basınç dayanımlarını arttırdığı belirlenmiştir [8]. Türkiye, hızla gelişen, büyüyen ve kalkınan bir ülkedir. Bunun neticesinde; ekonomik büyüme ve üretim artış1, kentleşme, nüfus artışı ve refah seviyesinin yükselmesi, giderek artan miktarda atık üretimine yol açmaktadır. Artan atık miktarı ise; atıksız veya olabildiğince az atıklı üretimi, atıkların geri kazanılmasını ve nihayetinde oluşan atıkların ekonomi ve çevre açısından en uygun şekilde bertarafını gerektirmektedir. Ülkemizde 2006 yılı verilerine göre 1.216 adet dökümhane bulunmaktadır ve bu iş yerlerinden toplam 1.294.500 ton üretim yapılmıştır. Yapılan bu üretime karş1lık, proseslerden yaklaşık 450.000 ton atık oluşmaktadır. Bu miktarın yaklaşık \%10-15'i demir tozu atıkları oluşturmaktadır. Kahramanmaraş'ta demirciler çarsısında faaliyet gösteren demirciler geleneksel yöntemlerle sicak demircilik işlemlerden sonra, gün sonunda dükkânlarından atık şekilde ortaya çıkan demir tozlarını toplayıp atmaktadırlar. Bu çalışma ile bu atıkların değerlendirilmesi amaçlanmıştır. Yapılan bu çalışma ile demir tozu atıkların harca katılmasıyla daha az girdi kullanıldığı için ekonomik beton elde edilecektir. Ayrıca bu durum ekolojik çevreninin korunmasına katk1 sağlayacaktır.

\section{MATERYAL VE METOT}

\subsection{Materyal}

\subsubsection{Demir Tozu}

Deneysel çalışmada kullanılan demir tozu Kahramanmaraş demirciler çarşısı ve sanayisindeki demirci atölyelerinden elde edilmiştir. Demir tozunun fiziksel analizi Çizelge 1'de, kimyasal analizleri Çizelge 2'de verilmiştir. Demir tozu kimyasal analizi Limak çimento tesislerinde yapılmıştır.

\subsubsection{Agrega}

Kullanılacak agregaların fiziksel özellikleri Çizelge 3'de elek analizi Çizelge 4'de verilmiştir. 
Çizelge 1. Demir tozunun fiziksel analizi

\begin{tabular}{|c|c|}
\hline Özellik & Demir tozu \\
\hline Özgül Ağırlık & 7,84 \\
\hline Boyut & $0-4 \mathrm{~mm}$ \\
\hline
\end{tabular}

Çizelge 2. Demir tozunun kimyasal analizi

\begin{tabular}{|c|c|}
\hline Bileşenler & Bileşenler (\%) \\
\hline $\mathrm{SiO}_{2}$ & 2,73 \\
\hline $\mathrm{Al}_{2} \mathrm{O}_{3}$ & 1,98 \\
\hline $\mathrm{Fe}_{2} \mathrm{O}_{3}$ & 90,14 \\
\hline $\mathrm{CaO}$ & 0,32 \\
\hline $\mathrm{MgO}$ & 0,04 \\
\hline $\mathrm{SO}_{3}$ & 0,04 \\
\hline $\mathrm{Na}_{2} \mathrm{O}$ & 1,92 \\
\hline $\mathrm{K}_{2} \mathrm{O}$ & 0,15 \\
\hline
\end{tabular}

Çizelge 3. Agregaların fiziksel özellikleri

\begin{tabular}{|c|c|c|}
\hline Özellik & $\begin{array}{c}\text { İnce } \\
\text { Agrega }\end{array}$ & $\begin{array}{c}\text { Kaba } \\
\text { Agrega }\end{array}$ \\
\hline Özgül Ağırlık & 2,74 & 2,65 \\
\hline $\begin{array}{c}\text { Sıkışık Birim } \\
\text { Ağırlık }\end{array}$ & 1,94 & 1,60 \\
\hline $\begin{array}{c}\text { Gevşek Birim } \\
\text { Ağırlık }\end{array}$ & 1,74 & 1,45 \\
\hline Su Emme (\%) & 1,10 & 0,25 \\
\hline İncelik Modülü & 3,17 & - \\
\hline $\begin{array}{c}\text { Aşınma } 100 \\
\text { Devir }\end{array}$ & - & 4,96 \\
\hline $\begin{array}{c}\text { Aşınma } 500 \\
\text { Devir }\end{array}$ & - & 22,75 \\
\hline
\end{tabular}

\subsection{4. Çimento}

Standartlar, çimentoların fiziksel ve mekanik özelliklerine sinırlamalar getirmektedir. $\mathrm{Bu}$ sınırları sağlayamayan çimentolar beton üretiminde kullanılamaz. Öte yandan hangi tür yapıda hangi tip çimentonun kullanılacağına karar verebilmek için çimentonun kimyasal özelliklerinin yanı sıra fiziksel ve mekanik özelliklerini de bilmek gerekir. $\mathrm{Bu}$ nedenle çimentoların özelliklerinin belirlenmesi beton teknolojisi açısından çok önemlidir. Çimentoların fiziksel ve mekanik özelliklerinin tayini TS EN 196'ya uygun olarak yapılmıştır.

Karışımda kullanılan çimentonun kimyasal ve fiziksel özellikleri sırasıyla Çizelge 5 ve Çizelge 6'da verilmiştir.

Çizelge 5. Çimentonun kimyasal özellikleri

\begin{tabular}{|c|c|}
\hline Bileşenler (\%) & Çimento \\
\hline $\mathrm{SiO}_{2}$ & 18,85 \\
\hline $\mathrm{Al}_{2} \mathrm{O}_{3}$ & 4,80 \\
\hline $\mathrm{Fe}_{2} \mathrm{O}_{3}$ & 2,40 \\
\hline $\mathrm{CaO}$ & 62,80 \\
\hline $\mathrm{MgO}$ & 2,5 \\
\hline $\mathrm{Na}_{2} \mathrm{O}+\mathrm{K}_{2} \mathrm{O}$ & 1,14 \\
\hline $\mathrm{SO}_{3}$ & 3,69 \\
\hline $\mathrm{Serbest} \mathrm{CAO}_{2}$ & 0,90 \\
\hline Kizdirma Kayb1 & 3,5 \\
\hline
\end{tabular}

Çizelge 6. Çimentonun fiziksel özellikleri

\begin{tabular}{|c|c|}
\hline Çimento Tipi & CEM I 42,5 \\
\hline Özgül Ağırlık $\left(\mathrm{g} / \mathrm{cm}^{3}\right)$ & 3,12 \\
\hline \begin{tabular}{c} 
Özgül Yüzey $\left(\mathrm{cm}^{2} / \mathrm{g}\right)$ \\
\hline $\begin{array}{c}\text { Ö Elek Üzerinde } \\
\text { Alan (\%) }\end{array}$
\end{tabular} & 3250 \\
\hline $\begin{array}{c}90 \mu \text { Elek Üzerinde } \\
\text { Kalan }(\%)\end{array}$ & 2,5 \\
\hline
\end{tabular}




\subsection{Metot}

\subsubsection{Beton Karışımların Hazırlanması}

TS 802'ye uygun olarak yapılan beton karışımda kumun yerine $\% 10, \% 20$ ve $\% 40$ oranlarında atık demir tozu kütlece ilave edilmiş ve kontrol örneği dâhil 4 çeşit örneğin karışım hesabı yapılmıştır.

Taze betonun işlenebilirliğini, akıcılığını tespit etmek amacıyla çökme deneyi yapılmıştır. Bunun için birçok yöntem geliştirilmiş olmakla beraber en çok kullanılan yöntem, slamp hunisi denilen bir aletle yapılan çökme deneyidir.

Numunelerin isimleri, karışım oranları ve kullanılan malzemeler Çizelge 7'de verilmiştir. Bulunan karışım ağırlıklarına göre agregalar ve çimento hassas bir şekilde tartılarak karılmıştır.

Numuneler için hazırlanan beton karışımları TS EN 12390-2'deki esaslar dikkate alınarak yapılmıştır. TS EN 12390-2'de öngördüğü şekilde hazırlanan beton harmanlarından alınan deney örneklerinin betonun tüm özelliklerini taşımasına dikkat edilmiştir.

\subsubsection{Harç Numunelerin Hazırlanması}

TS EN 196-1'e göre yapılan karışım hesabından Rilem kumdan \% 10, 20 ve 40 DT yer değiştirilerek $4 \times 4 \times 16 \mathrm{~cm}$ boyutlu harç numuneler hazırlanmıştır.

\subsubsection{Beton Numunelerin Basınç Dayanımı}

Beton basınç dayanımı $10 \mathrm{~cm}$ boyutlarındaki standart küp numuneler kullanılarak saptanmıştır (Şekil 1).

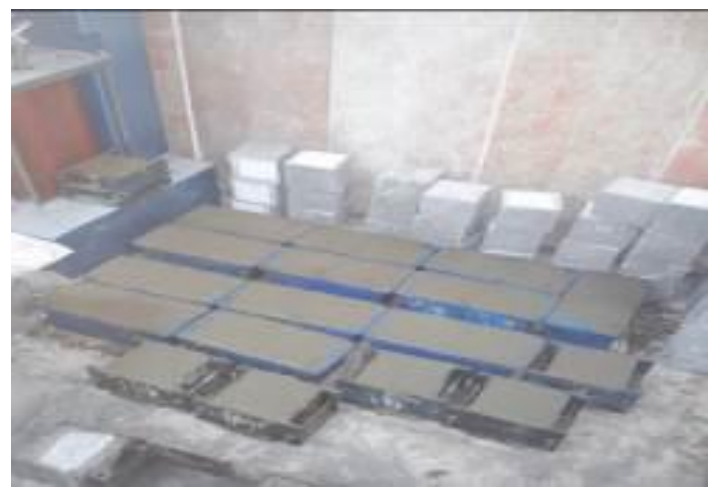

Şekil 1. Üretilen 100x100x100 mm beton numuneleri

Çizelge 7. $1 \mathrm{~m}^{3}$ beton karışımı için malzeme oranları ve numunelerin isimleri

\begin{tabular}{|c|c|c|c|c|c|c|c|c|}
\hline \multirow{2}{*}{ Örnek Ad1 } & \multicolumn{5}{|c|}{ Beton Bileşenleri } & \multicolumn{3}{c|}{ Yaş Beton Özellikleri } \\
\cline { 2 - 9 } & $\begin{array}{c}\mathrm{Su} \\
\left(\mathrm{kg} / \mathrm{m}^{3}\right)\end{array}$ & $\begin{array}{c}\text { Çimento } \\
\left(\mathrm{kg} / \mathrm{m}^{3}\right)\end{array}$ & $\begin{array}{c}\text { Çak1 } \\
\left(\mathrm{kg} / \mathrm{m}^{3}\right)\end{array}$ & $\begin{array}{c}\text { Kum } \\
\left(\mathrm{kg} / \mathrm{m}^{3}\right)\end{array}$ & $\begin{array}{c}\text { Ikame } \\
\left(\mathrm{kg} / \mathrm{m}^{3}\right)\end{array}$ & $\begin{array}{c}\text { Slamp } \\
(\mathrm{mm})\end{array}$ & $\begin{array}{c}\text { Yoğunluk } \\
\left(\mathrm{t} / \mathrm{m}^{3}\right)\end{array}$ & $\begin{array}{c}\text { Beton Isıs1 } \\
\left({ }^{\circ} \mathrm{C}\right)\end{array}$ \\
\hline $\mathrm{R}$ & 180 & 360 & 1120 & 720 & - & 72 & 2,50 & 20 \\
\hline DT10 & 180 & 360 & 1120 & 648 & 72 & 65 & 2,53 & 20 \\
\hline DT20 & 180 & 360 & 1120 & 576 & 144 & 62 & 2,58 & 20 \\
\hline DT40 & 180 & 360 & 1120 & 432 & 288 & 57 & 2,63 & 19 \\
\hline
\end{tabular}


Beton numunelerin basınç dayanımları TS EN 12390-3'e göre belirlenmiştir. Her grup örnek için suyunda bekletilen numuneler 7, 28, 90 günlük basınç dayanımlarını belirlenmek üzere her yaş grubundan üçer adet numune üretilmiştir.

\subsubsection{Beton Numunelerin Ultrasonik Hiz Ölçümü ile Basınç Dayanımı}

Ultrases hızı yöntemi beton elemana doğru gönderilen vibrasyonel enerjinin hızının ölçülmesinden ibarettir. Beton bloğun bir yüzeyinden içeriye gönderilen ses üstü dalgaların, bloktaki diğer bir yüzeye kadar zamanda geçtiği ölçüldükten sonra, dalga eşitlik (1) kullanılarak hesaplanmaktadır:

$V=(S / t) \times 10^{6}$

Burada; $\mathrm{V}=\mathrm{P}$ dalga hızı (metre/saniye),

$\mathrm{S}=$ Beton bloğun ses üstü dalga gönderilen yüzeyi ile dalganın alındığı yüzeyi arasındaki mesafe (metre),

$\mathrm{t}=\mathrm{P}$ dalganın gönderilmiş olduğu beton yüzeyinden, alındığı yüzeye kadar geçen zamandır (mikro saniye). Beton numunelerin Ultrasonik hız ölçümü ile basınç dayanımları ASTM C597'e göre belirlenmiştir. Üretilen numuneler aşağıdaki şekillerde gösterildiği gibi Ultrasonik ses geçişi deneyine tabi tutulmuşlardır (Şekil 2).

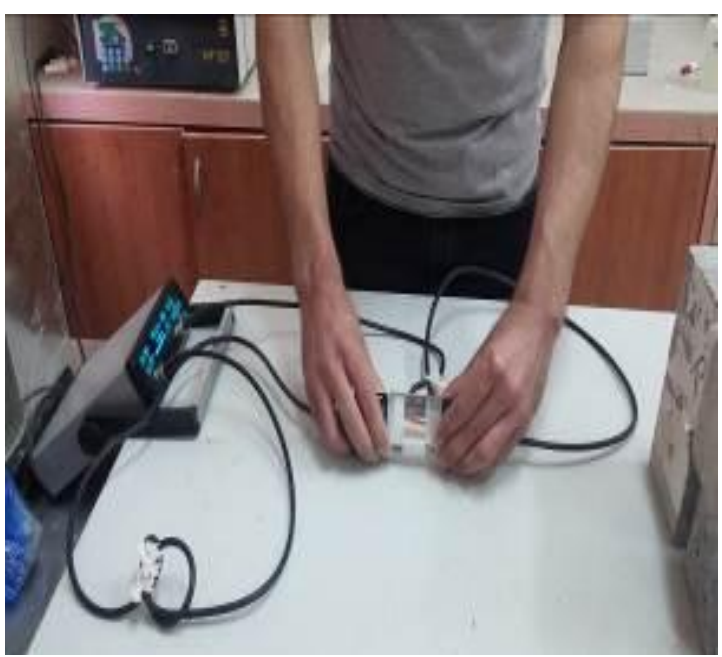

Şekil 2. Ultra ses cihazı ve deneyin yapılışı

\subsubsection{Harç Numunelerin Eğilme Dayanımı}

Eğilmede çekme aletinin yükleme düzeni birbirinden $100 \mathrm{~mm} \pm 0,5 \mathrm{~mm}$ uzaklıkta olan $100 \mathrm{~mm}$ çaplı iki destek silindirden ibarettir. 4 farklı karışıma sahip ve her bir karışım için 3 adet $4 \times 4 \times 16 \quad \mathrm{~cm}$ üretilen harç numuneleri TS EN 196-1standardına uygun olarak yapılmıştır.

\subsubsection{Harc Numunelerin Basınç Dayanımı}

Basınç deneyi iki parçaya bölünmüş olan yarım prizmalar kullanılır. Her yarım prizma basınç aleti kullanılarak yan yüzeylerinden yüklemek suretiyle deneye tâbi tutulur. 3, 7, 28, 60 ve 90 günlük 4 numune ve her bir karışım için 3 adet $4 \times 4 \times 16 \mathrm{~cm}$ üretilen harç numuneleri TS EN 196-1 standardına uygun yapılmıştır.

\subsubsection{Beton Numunelerin Sülfat Dayanıklılığ}

\subsubsection{Basınç Dayanımı}

Çalışmada kum yerine kütlece $\% 10, \% 20$ ve $\% 40$ oranlarında demir tozu ikame edilmesiyle, maksimum çapı $16 \mathrm{~mm}$ olan agregalar ile üretilen 10x10x10 cm boyutlarındaki küp numuneler sülfat ve tuz ortaminda bekletildikten sonra basınç dayanımları araştırılmıştır (Şekil 3).

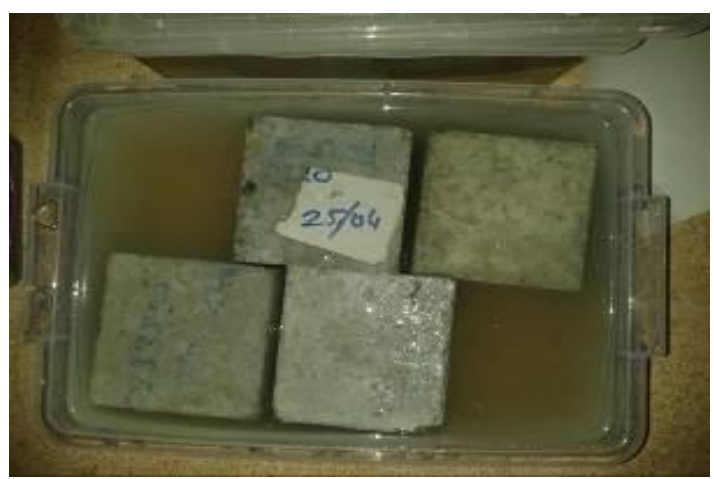

Şekil 3. $\% 10 \quad \mathrm{MgSO}_{4}$ ve $\% 10$ tuz çözeltisinde bekletilen beton numuneleri

\subsubsection{Kütle Kaybı}

Numuneler 60 gün sonra $\% 10 \mathrm{MgSO}_{4}$ ve $\% 10$ Tuz çözeltisinden çıkarılarak etüvde $105^{\circ} \mathrm{C}$ 'de 24 saat 
ağırlığı değişmez hale gelinceye bekletilmiştir. Etüvden çıkarılan numuneler oda sıcaklığına erişinceye bekletildikten sonra değişmez ağırlıkları belirlenmiştir. Daha sonra numunelerin ağırlık değişimleri bulunmuştur.

\subsubsection{Harç Numunelerin Sülfat Dayanıklılığ}

\subsubsection{Basınç Dayanımı}

Çalışmada kum yerine \%10, 20 ve 40 oranlarında demir tozunun ağırlıkça ikame edilmesi ile üretilen $4 \times 4 \times 16 \mathrm{~cm}$ boyutlarındaki harç numuneler sülfat ortamında bekletildikten sonra basınç dayanımları araştırılmıştır (Şekil 4).

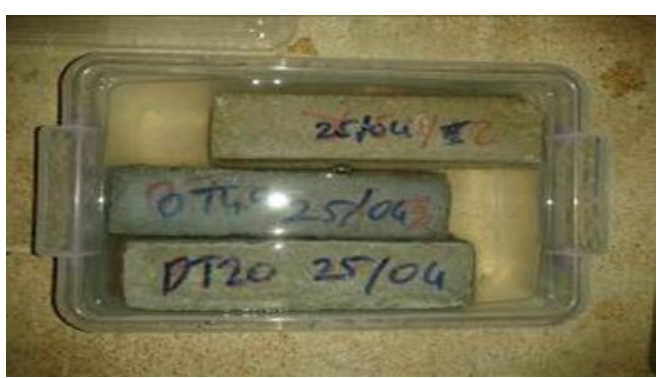

Şekil 4. $\% 10 \quad \mathrm{MgSO}_{4}$ ve $\% 10$ tuz çözeltisinde bekletilen harç numuneleri

\subsubsection{Küitle Kaybı}

Üretilen numuneler 28 gün sonunda kür havuzundan çıkarılmıştır. Kür havuzundan çıkarılan numuneler $105^{\circ} \mathrm{C}$ de etüve konularak 24 saat bekletilmiştir (Şekil 5). Daha sonra numuneler hassas terazi ile tartılmıștır. \%10 $\mathrm{MgSO}_{4}$ ve $\% 10$ Tuz çözeltisi içine konularak 60 gün bekletilmiştir.

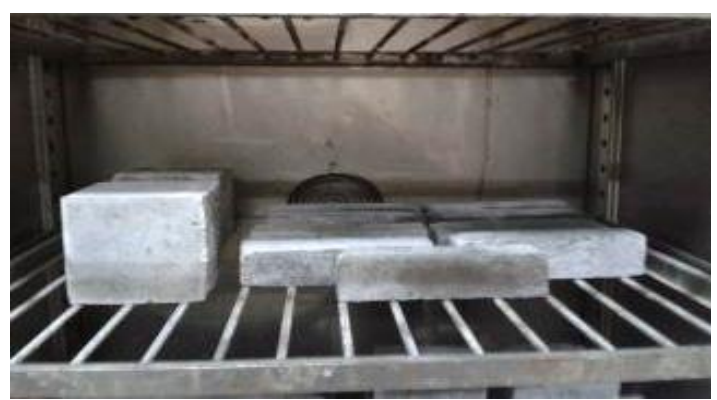

Şekil 5. Etüvde bekletilen harç ve beton numuneler

\subsubsection{Betonun Yüzey Aşınmalarının Tayini}

Yüzey aşınmasını bulabilmek için 10x10x10 cm boyutlarında küp örnekler üretilmiş ve 28 günlük yaşa ulaştıktan sonra kesilerek $71 \times 71 \times 71 \mathrm{~mm}$ boyutlarında yeni örnekler elde edilmiştir (Şekil $6)$.

Döner diskin 22 devri 1 periyot olarak kabul edilerek ve 16 periyotluk aşındırma uygulanmıştır. $\mathrm{Bu}$ ilk periyotluk işlem tamamlandıktan sonra yüzey temizlenerek tekrar $20 \mathrm{~g}$ standart zımpara tozu yüzeye homojen olarak tekrar yayılmış ve bu işlem işaretlenen 4 yüzeye tek tek uygulanmıştır. $\mathrm{Bu}$ işlem sonunda her bir örneğe toplam 352 devir aşındırma uygulanmış olmaktadır. İşlem tamamlandıktan sonra her bir noktadan ayrı ayr1 0.01 duyarlıktaki mikrometre ile ölçümleri yapılmış ve kalınlıktaki azalmanın yardımıyla aşınma kaybı aşağıdaki bağıntı ile hesaplanmıştır (DIN 52108, 2002).

Hacimsel kayıp aşağıdaki ifade ile bulunmuştur (Eşitlik 1).

$\Delta V=\frac{\Delta m}{\delta R}$

$\Delta V=$ Hacimsel kayıp,

$\Delta m=16$ periyot sonundaki ağırlık kaybı $(\mathrm{g})$, $\delta R=$ Örnek birim hacim ağırlığı,

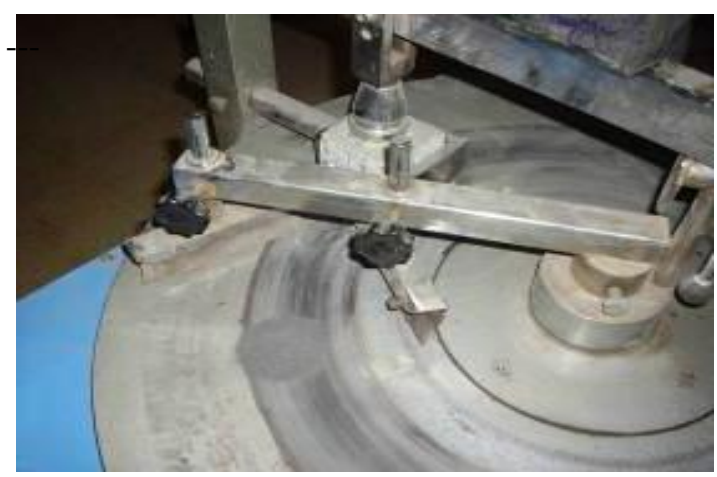

Şekil 6. Böhme deney aleti, numune ve zımpara tozu 


\subsubsection{Kılcal Su Geçirimliliği Deneyi}

TS 802'ye göre karışımı hazırlanan ve TS EN 12390-2 usullerine göre hazırlanan beton numuneler 28 gün süreyle kür edildikten sonra $105 \mathrm{C}^{\circ}$ 'de değişmez ağırlığa gelinceye kadar kurutularak içerisindeki nem tamamen yok edilmiştir. Daha sonra oda sıcaklığında soğumaya bırakılmıştır. Daha sonra numunelerin yan yüzeyleri sınırlı bir alandan su emebilmesi için su geçirmez malzeme ile kaplanmıştır.

\section{BULGULAR VE TARTIŞMA}

\subsection{Beton Numunelerin Basınç Dayanımları}

Üretilen beton numunelerin 7, 28, 60 ve 90 günlük basınç dayanım verileri Şekil 7' de verilmiştir.

7 günlük basınç dayanım sonuçlarına göre $\% 10$ atık demir tozu (DT) katkılı örneklerin basınç dayanımı referans numunesi basınç dayanımından \%30, \%70 DT katk1lı örneklerin \%36, \%40 DT katkılı örneklerin dayanımı $\% 30$ daha fazla bulunmuştur (Şekil 7).

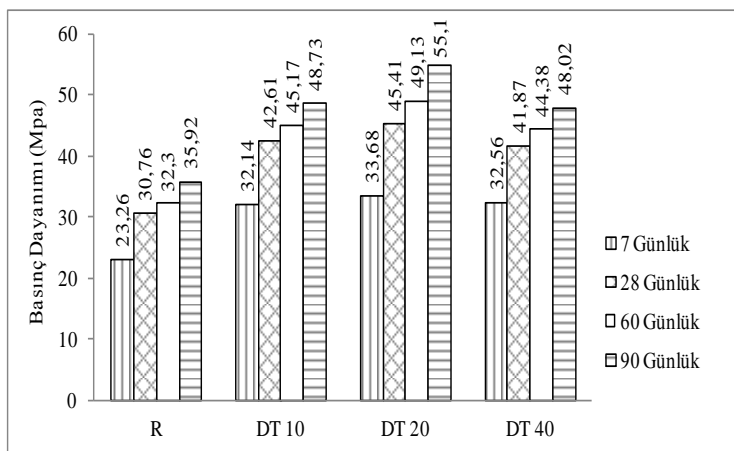

Şekil 7. 7, 28, 60 ve 90 günlük beton numunelerin basınç dayanımlar

Katkılar \%10 ve \%20 oranında arttıkça basınç dayanımında da artış gözlemlenmektedir. \% 30 katk1lı numune \%20 katk1lı numuneden daha düşük bir basınç dayanımı elde edilmiştir. $\mathrm{Bu}$ durum DT katkı oranının optimum seviyesinin \%20 olduğunu göstermektedir. Bu orana kadar DT katkısı dolgu etkisi yaratmış ve numunelerin boşlukları doldurulmuştur. Ayrıca demir tozu çimento-agrega ara yüzeyinin gelişmesinde katk1 sağlamıştır. \%40 katkı oranındaki numunenin basınç dayanımının düşük çıkmasının nedeni demir tozunun tane şekli ve granülometresinden olabilir.

28 günlük basınç dayanımlarına göre $\% 10, \% 20$ ve \%40 DT katkılı örnekler basınç dayanımlara referans örneğe göre sirayla $\% 45, \% 50$ ve $\% 40$ fazla bulunmuştur. Bunlar kayda değer basınç dayanımı artışıdır. Bu sonuçlar söz konusu DT atıkların değerlendirilebileceğini göstermiştir. 60 günlük basınç dayanımına göre $\% 10, \% 20$ ve \%40 DT katkılı örnekler basınç dayanımı referansa göre sirayla $\% \quad 45, \% 52$ ve $\% 43$ daha fazla bulunmuştur. Burada ilginç olan bir durum da 90 günlük basınç dayanımı ile 7 günlük basınç dayanımlar arasındaki artışlardır. Zira referans numunesi 60 günde 7 günlük basınç dayanımından $\% 30$ fazla iken \%10 DT katkılı örnekte \%35 ve $\% 20$ DT katkılı örnekler $\% 40$ daha fazla bulunmuştur. $\mathrm{Bu}$ sonuçlar betonda mineral katkılara zaman içerisinde daha etkili olduğunu göstermektedir. Yani, mineral katkılı betonda zamanla dayanım artışı daha fazla olmaktadır.

90 günlük basınç dayanımı en büyük olan $\% 20$ demir tozu katkılı numune, en düşük olan ise kontrol numunesidir. 7, 28, 60 ve 90 günlük basınç dayanımlarında, tüm katkılı örneklerde katk1 oranı arttıkça dayanım artmaktadır.

\subsection{Harç Numunelerin Basınç Dayanımları}

Üretilen harç numunelerin 3, 7, 28, 60 ve 90 günlük harç numunelerin basınç dayanımları Şekil 8'de verilmiştir.

3 günlük basınç dayanımı en yüksek olan \%20 DT katkılı numune, en düşük olan ise referans numunesidir. DT katkılı numunelerin basınç dayanımları referans numunesinin basınç dayanımından fazla çıkmıştır.

7 günlük basınç dayanımı en yüksek olan \%20 demir tozu katkılı numune, en düşük olan ise kontrol numunesidir. Tüm katkılı örneklerin basınç dayanımları referans numunesinden yüksek çıkmıştır. 


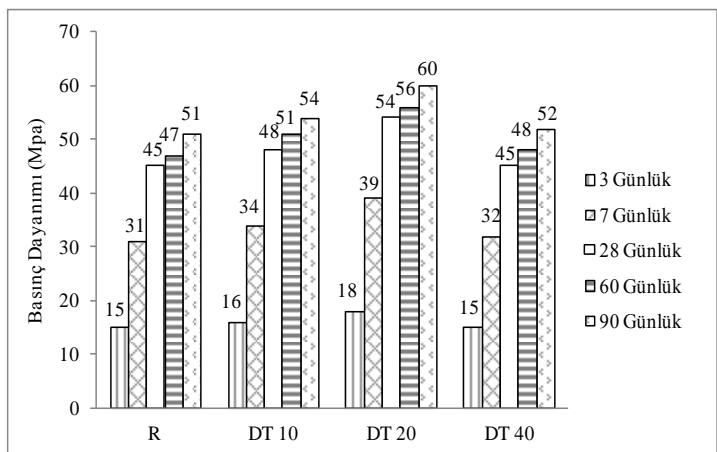

Şekil 8. 3, 7, 28, 60 ve 90 günlük harç numunelerin basınç dayanımları

28 günlük basınç dayanımı en yüksek olan \%20 demir tozu katkılı numune, en düşük olan ise kontrol numunesidir. Tüm katkılı örneklerin basınç dayanımları referans numunesinden yüksek çıkmıştır.

60 günlük basınç dayanımı en yüksek olan $\% 20$ demir tozu katkılı numune, en düşük olan ise kontrol numunesidir. Tüm katkılı örneklerin basınç dayanımları referans numunesinden yüksek çıkmıştır.

90 günlük basınç dayanımı en yüksek olan \%20 demir tozu katkılı numune, en düşük olan ise referans numunedir. Tüm katkılı örneklerin basınç dayanımları referans numunesinden yüksek çıkmıştır. DT katkılı harç numunelerinin basınç dayanımları olumlu katkılar göstermiștir. 3, 7, 28, 60 ve 90 günlük harç numunelerinde $\% 10$ DT katkılı numunelerin basınç dayanımları referans numunesine göre sirasiyla $\% 10, \% 8,3, \% 7, \% 7$, $\% 6,2$ olmuştur. $\mathrm{Bu}$ oranlar \%20 DT katk1lı örnekler için ise \%21,6 \%21,8, \%16,4, \%16,4, $\% 15,2$ oranda olmuştur.

\subsection{Harc Numunelerin Eğilme Dayanımları}

Üretilen harç numunelerin 3, 7, 28, 60 ve 90 günlük harç numunelerin eğilme dayanımları Şekil 9'da verilmiştir.

3 günlük eğilme dayanımı en büyük olan $\% 20$ katkılı numune, en düşük olan ise referans demir tozu katkılı numunedir.

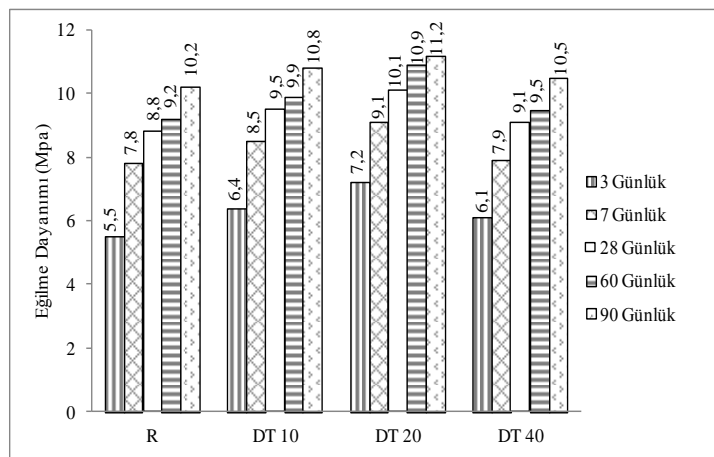

Şekil 9. 3, 7, 28, 60 ve 90 günlük harç numunelerin eğilme dayanımları

7 günlük eğilme dayanımı en büyük olan $\% 20$ katkılı numune, en düşük olan ise referans demir tozu katkılı numunedir.

28 günlük eğilme dayanımı en büyük olan $\% 20$ katkılı numune, en düşük olan ise referans demir tozu katkılı numunedir.

60 günlük eğilme dayanımı en büyük olan $\% 20$ katkılı numune, en düşük olan ise referans demir tozu katkılı numunedir.

90 günlük eğilme dayanımı en büyük olan \%20 katkılı numune, en düşük olan ise referans demir tozu katkılı numunedir. DT katkılı numunelerin eğilme dayanımları önemli oranda artmıştır. \%10 DT katk1lı numunelerin 3, 7, 28, 60 ve 90 günlük eğilme dayanımları referans numunesine göre $\% 15, \% 8,5, \% 7, \% 6,6, \% 5,7$ iken $\% 20$ DT katkıl1 örneklerde ise \%24,3, \%13,8, \%13,2, \%14,6, \%9 olmuştur. \%40 DT katkılı örneklerde de eğilme dayanımları \%20 DT katkılı örneklere göre azalmış olsa da referans numunesinin dayanımından daha yüksek bulunmuştur.

\subsection{Beton Numunelerin Ultrasonik Hız Ölçümü ile Basınç Dayanımları}

Beton numunelerin 7, 28, 60 ve 90 günlük ultrasonik hız ölümü il basınç dayanımları Şekil 10'da verilmiştir. DT katkılı numunelerin eğilme dayanımları önemli oranda artmıştır. \%10 DT katkılı numunelerin 3, 7, 28, 60 ve 90 günlük eğilme dayanımları referans numunesine göre

Ç.Ü.Müh.Mim.Fak.Dergisi, 30(1), Haziran 2015 
$\% 15, \% 8,5, \% 7, \% 6,6, \% 5,7$ iken $\% 20$ DT katk1l örneklerde ise \%24,3, \%13,8, \%13,2, \%14,6, \%9 olmuştur. \%40 DT katkılı örneklerde de eğilme dayanımları \%20 DT katkılı örneklere göre azalmış olsa da referans numunesinin dayanımından daha yüksek bulunmuştur. Ultrasonik hız ölçümüyle elde edilen basınç dayanımlarına göre \%10 DT katkılı örneklerin 7, 28, 60 ve 90 günlük basınç dayanımları referans numunesine göre sirasiyla \%21,8, \%31,7, \%26, $\% 26,5$ iken \%20 DT katkılı numunelerin 7, 28, 60 ve 90 günlük basınç dayanımları sırasıyla referans numunesine göre $\% 26,4, \% 40,4, \% 29, \% 30,7$ ve $\% 40$ DT katkılı numunelerin $7,28,60$ ve 90 günlük basınç dayanımları sırasıyla \%16,6, \%26,3, $\% 26,3, \% 20,9, \% 23,4$ olmuştur. Bu sonuçlar pres ile elde edilen değerler ile uyum içerisindedir.

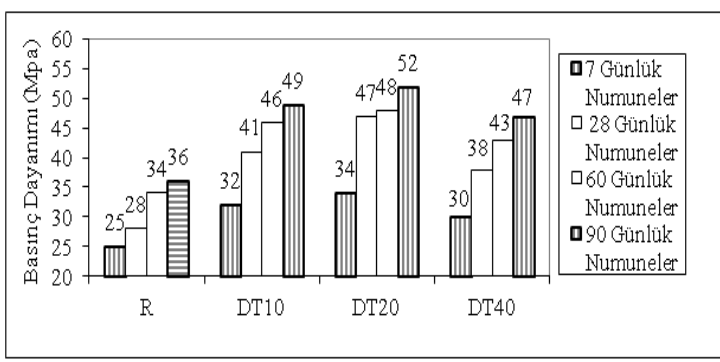

Şekil 10. 7, 28, 60 ve 90 günlük beton numunelerin ultrasonik hız ölçümü ile basınç dayanımları

\subsection{Beton Numunelerinin Sülfat Dayanıklılığı}

\subsubsection{Magnezyum Sülfat Çözeltisi İçindeki Numunelerin Kütle Kayıpları}

$\% 10 \mathrm{MgSO}_{4}$ çözeltisinde bekletilen beton numunelerden 60 gün sonraki kütle kayıpları Şekil 11'de verilmiştir.

Şekilden de anlaşılacağı üzere magnezyum sülfat çözeltisine maruz kalan R, DT10, DT20 ve DT40 numunelerinde kütle kaybı meydana gelmiştir. En yüksek kütle kaybı referans numunesinde en düşük kütle kayb1 DT20 numunesinde meydana gelmiştir. Gözlemlenen bu kütle kaybının sebebi olarak ortamda mevcut olan magnezyum sülfat nedeniyle numunelerinin dış yüzeylerinin hemen altında oluşan brucit ürünü ile ilgili olduğu düşünülmektedir. DT20 numunesinde meydana gelen kütle artışının demir tozu katkılı diğer numunelere oranla daha düşük oranda gerçekleşmesi basınç dayanımının yüksek olmasıyla paralel olarak boşluk oranının düşük olmasıly açıklanabilir Şekil 12'de 60 günlük sülfat çözeltisinde bekletilen beton numunelerin basınç dayanımları verilmiştir.

60 günlük Magnezyum Sülfatta bekletilen numunelerin basınç dayanımları incelendiğinde farklı sonuçlar gözlemlenmiştir. Referans numunesinin basınç dayanımı \%33,7 azalırken $\% 10,20$ ve 40 DT katk1l numunelerde bu oran sırasıly $\% 12,9, \% 14,2, \% 8,7$ oranları olmuştur. Burada en düşük basınç dayanımı azalması \%20 DT katkılı numunelerde gözlemlenmiştir. Genellikle DT katkılı numuneler Magnezyum Sülfata daha dayanıklı olduğu söylenebilir. Test süresi daha uzun tutulduğunda oranların daha da azaldığı söylenebilir.

\subsubsection{Tuz Çözeltisi İçindeki Numunelerin Basınç Dayanımları}

Şekil 13'de 60 günlük tuz çözeltisinde bekletilen beton numunelerin kütle değişimleri verilmiştir. Tuz çözeltisinde 60 gün bekletildikten sonra test edilen numunelerin basınç dayanımları Referans, $\% 10, \% 20$ ve \%40 DT katkılı örneklerde değişik oranlarda azalmıştır. Bu oran sırasıyla \%4, \%17,9, $\% 2,2, \% 16,2$ olmuştur. Burada referans numunesi en çok dayanım kaybına uğrarken en az dayanım kayb1 \%20 DT katkılı numune göstermiştir. Bu sonuçlar Magnezyum Sülfat çözeltisinde bekletilen numunelerden elde edilen sonuçlara paralellik göstermiştir.

\subsection{Harç Numunelerinin Sülfat Dayanıklılığı}

\subsubsection{Magnezyum Sülfat Çözeltisi İçindeki Numunelerin Durabilite Özellikleri}

Şekil 14'de 60 günlük sülfat çözeltisinde bekletilen harç numunelerin kütle değişimi verilmiştir.

Magnezyum Sülfat çözeltisinde bekletilen harç numunelerinin kütle kaybı Şekil 25'de 


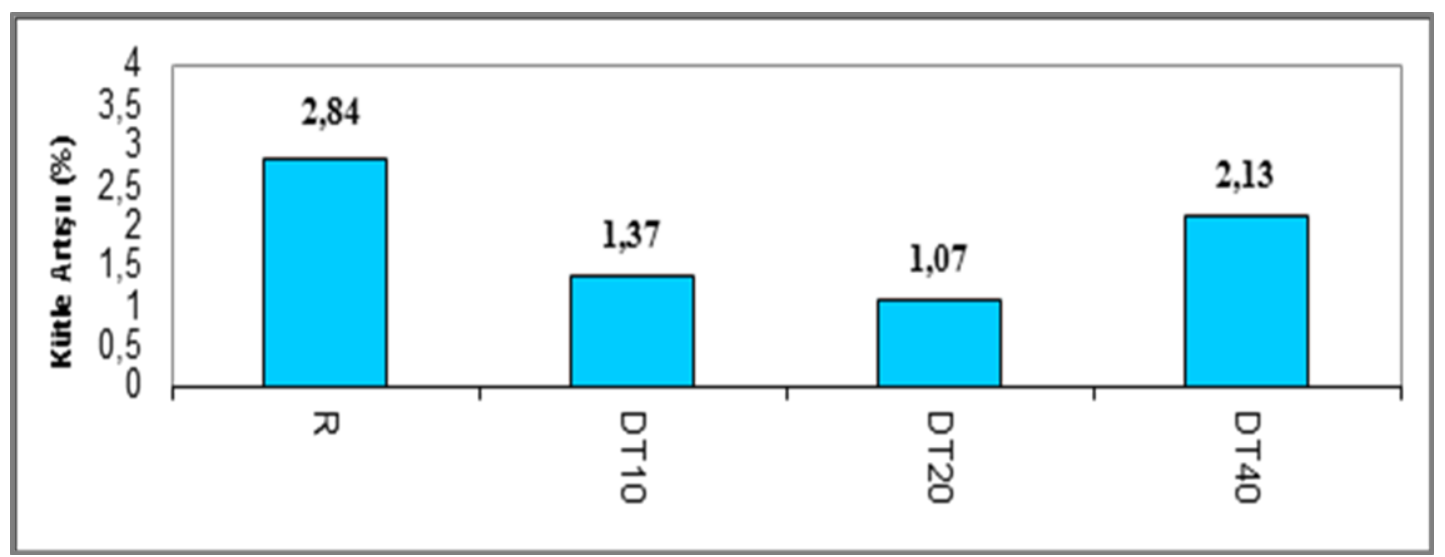

Şekil 11. Magnezyum Sülfat çözeltisinde bekletilen beton numunelerin kütle kayıpları

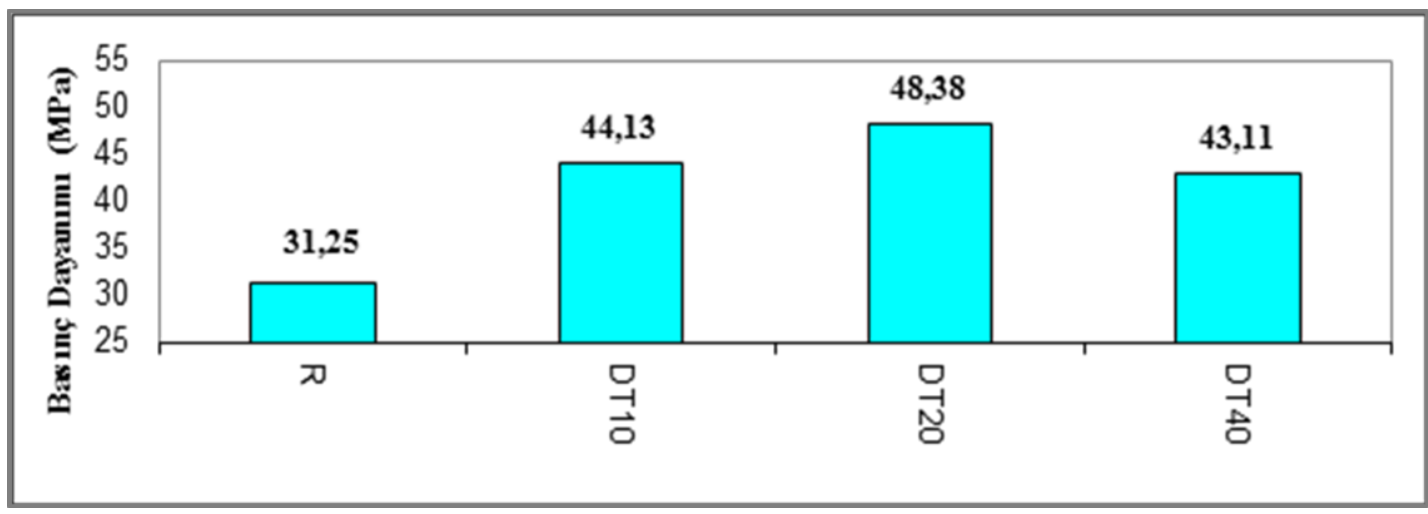

Şekil 12. Magnezyum Sülfat çözeltisinde bekletilen beton numunelerin basınç dayanımları

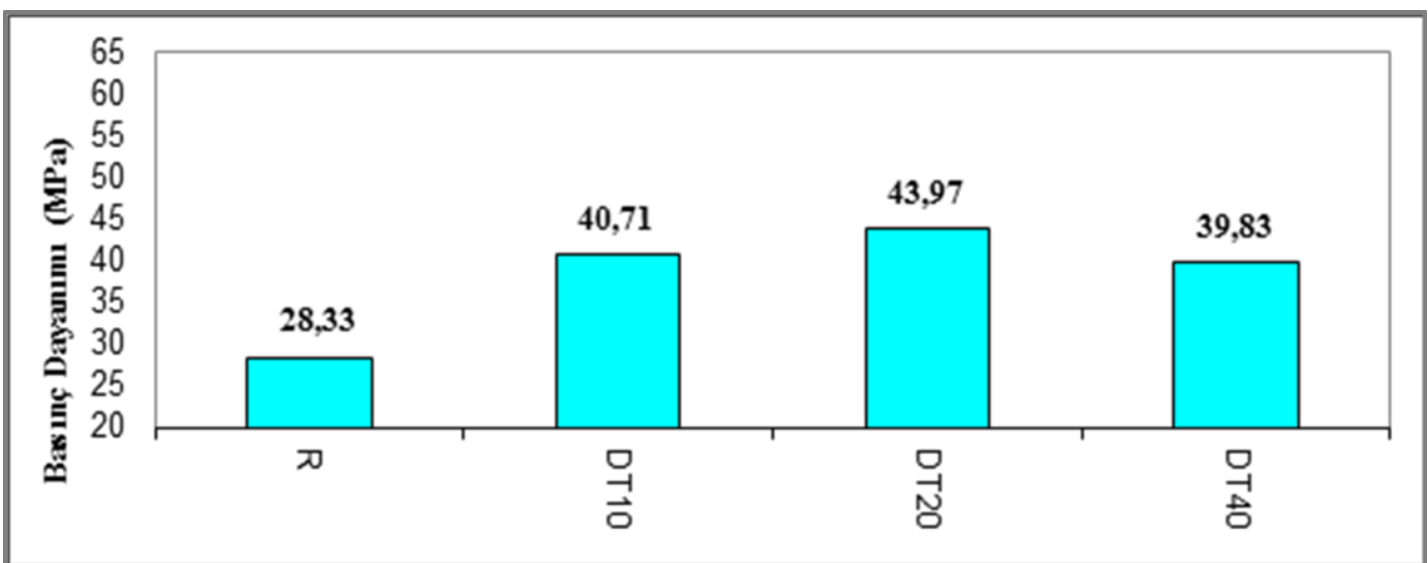

Şekil 13. Tuz çözeltisinde bekletilen beton numunelerin basınç dayanımları 
verilmektedir. Şekilden de anlaşılacağı üzere magnezyum sülfat çözeltisine maruz kalan $\mathrm{R}$, DT10, DT20 ve DT40 numunelerinde kütle kayb1 meydana gelmiştir. En yüksek kütle kaybı referans numunesinde en düşük kütle artışı DT20 numunesinde meydana gelmiştir.

Gözlemlenen bu kütle kayıplarının sebebi olarak ortamda mevcut olan magnezyum sülfat nedeniyle numunelerinin dış yüzeylerinin hemen altında oluşan brucit ürünü ile ilgili olduğu düşünülmektedir. DT20 numunesinde meydana gelen kütle kaybının demir tozu katkılı diğer numunelere oranla daha düşük oranda gerçekleşmesi basınç dayanımının yüksek olmasıyla paralel olarak boşluk oranının düşük olmasıyla açıklanabilir. Şekil 15'de Harç numunelerin sülfat çözeltisi öncesi ve sonrasındaki eğilme dayanımları verilmiştir Şekil $15^{\prime}$ 'de Magnezyum Sülfat çözeltisinde bekletilen harç numunelerinin eğilme dayanımları verilmiştir. Elde edilen sonuçlara göre demir tozu katkılı numunelerin referans numunesine oranla eğilme dayanımı artışı daha yüksek oranda gerçekleşmiştir. En az eğilme dayanımı artışı referans numunesinde, en fazla eğilme dayanımı artış1 DT20 numunesinde görülmüştür. Magnezyum Sülfatta 60 gün bekletilen harç numunelerin eğilme dayanım kayıpları Referans,.\%10, \%20 ve \%40 DT katkılı numuneler için sirasıyla \%0,5, \%11，\%6, \%10,5，\%9 olmuştur. Buradan genellikle eğilme dayanımında bir müddet artış olmuştur.

Basınç dayanım kayıpları ise sırasıyla \%3, \%0,8, $\% 1,2, \% 0,7$, oranlarında olmuştur. Bu sonuçlar test süresinin yeterli olmadığı göstermiştir. Çok küçük de olsa basınç dayanımları düşüşler göstermiştir. Şekil 16'da 60 günlük sülfat çözeltisinde bekletilen harç numunelerin basınç dayanımları verilmiştir. Şekil 16'da Magnezyum Sülfat çözeltisinde bekletilen harç numunelerinin basınç dayanımları verilmiştir. Elde edilen sonuçlara göre demir tozu katkılı numunelerin referans numunesine oranla basınç dayanımı artışı daha yüksek oranda gerçekleşmiştir. En az basınç dayanımı artışı referans numunesinde, en fazla basınç dayanımı artışı DT20 numunesinde görülmüştür.

\subsubsection{Tuz Çözeltisi İçindeki Numunelerin Durabilite Özellikleri}

Harç numunelerin basınç dayanımları ve kütle değişimleri \%10 tuz çözeltisinde bekletilen numunelerle araştırılmıştır. \%10 tuz çözeltisinde bekletilen harç numunelerden 60 günlük veriler alınmıştır. Şekil 17'de 60 günlük tuz çözeltisinde bekletilen harç numunelerin kütle değişimleri verilmiştir.

Tuz çözeltisinde tüm numunelerde ağırlık kaybı meydana gelmiştir. En fazla ağırlık kaybı referans numunesinde, en az ağırlık kayb1 DT20 numunesinde görülmüştür. Buna sebep olarak demir tozu katkılı numunelerin basınç dayanımına paralel olarak geçirimliliğinin referans numunesine oranla daha düşük olması gösterilebilir. DT20 numunesinde meydana gelen kütle kaybının demir tozu katkılı diğer numunelere oranla daha düşük oranda gerçekleşmesi basınç dayanımının yüksek olmasıla paralel olarak boşluk oranının düşük olmasıyla açıklanabilir. Şekil 18 'de 60 günlük tuz çözeltisinde bekletilen harç numunelerin eğilme dayanımları verilmiştir.

Şekil 18'de Tuz çözeltisinde tüm numunelerde eğilme dayanımında kayıp meydana gelmiştir. En fazla eğilme dayanımı kaybı referans numunesinde, en az eğilme dayanımı kaybı DT20 numunesinde görülmüştür. Buna sebep olarak demir tozu katkılı numunelerin basınç dayanımına paralel olarak geçirimliliğinin referans numunesine oranla daha düşük olması sebebiyle çözelti etkisinin iç kısımlara ilerlemesinin daha az olması şeklinde açılanabilir. DT20 numunesinde meydana gelen dayanım kaybının demir tozu katkılı diğer numunelere oranla daha düşük oranda gerçekleşmesi basınç dayanımının yüksek olmasıyla paralel olarak boşluk oranının daha düşük olmasıyla açıklanabilir. Şekil 19'da 60 günlük tuz çözeltisinde bekletilen harç numunelerin basınç dayanımları verilmiştir.

\subsection{Beton Numunelerin Yüzey Aşınma Oranları}

Böhme metoduyla yüzey aşınması için üretilen kontrol ve 3 adet değişik oranlarda katkı içeren 


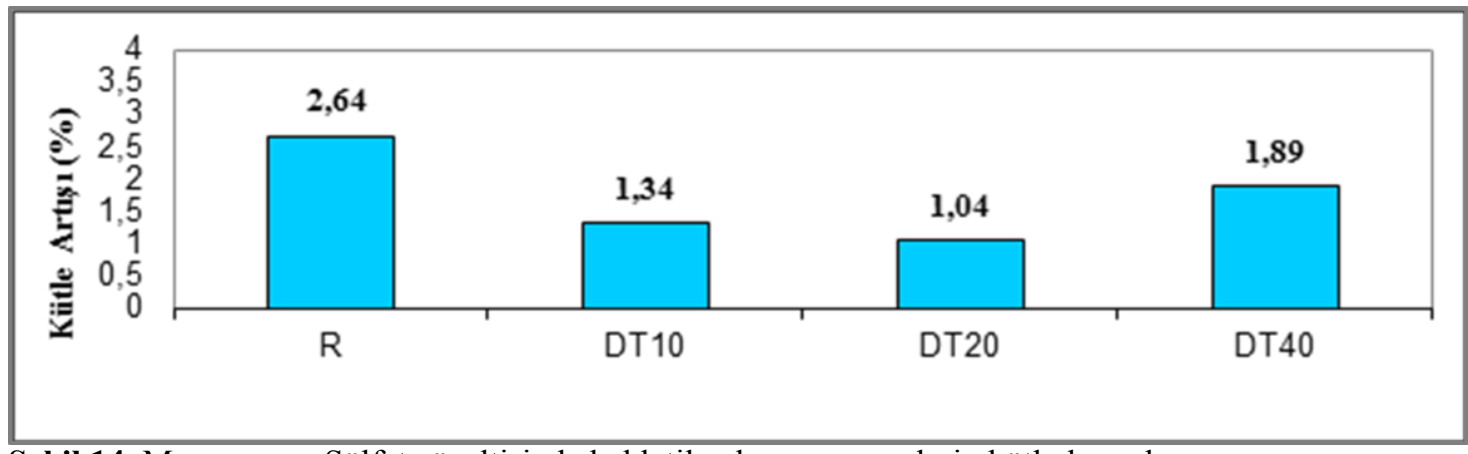

Şekil 14. Magnezyum Sülfat çözeltisinde bekletilen harç numunelerin kütle kayıpları

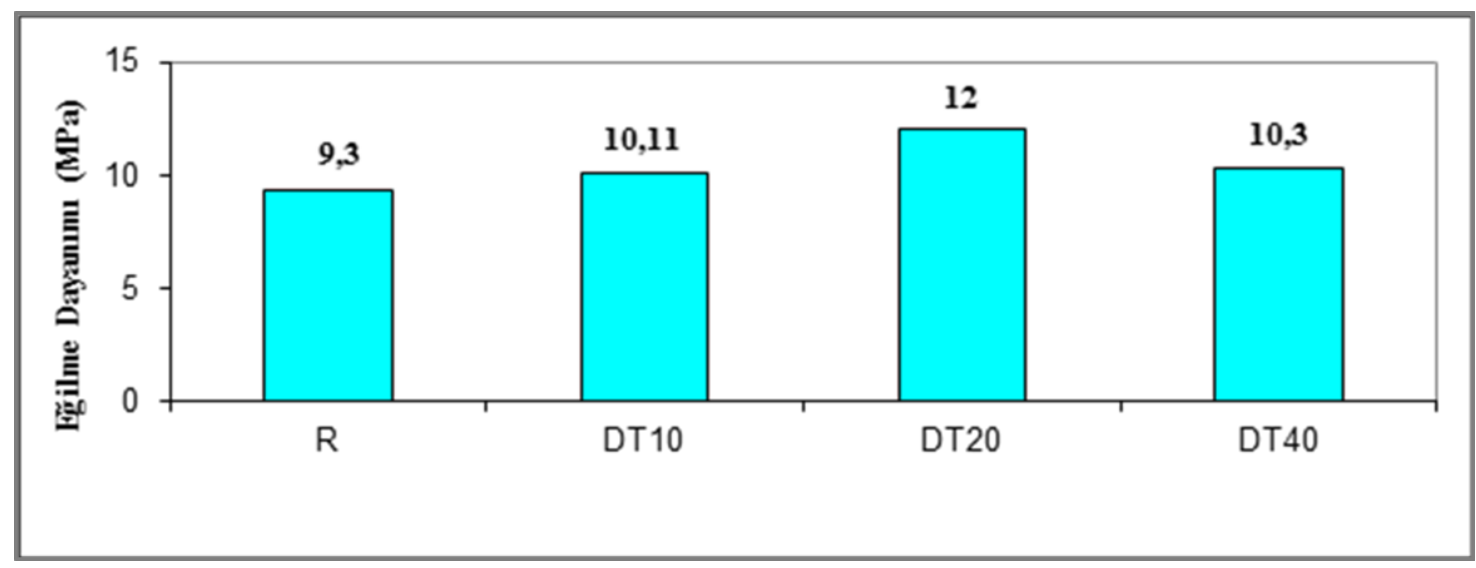

Şekil 15. Magnezyum Sülfat çözeltisinde bekletilen harç numunelerin eğilme dayanımları

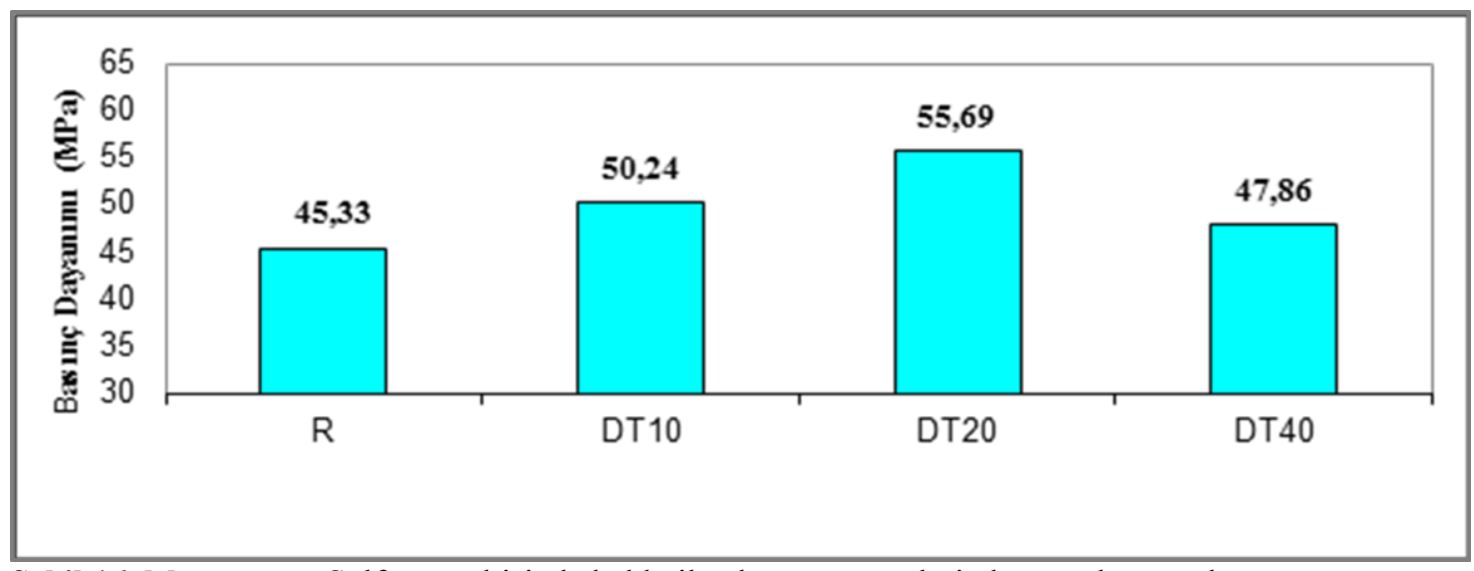

Şekil 16. Magnezyum Sülfat çözeltisinde bekletilen harç numunelerin basınç dayanımları 


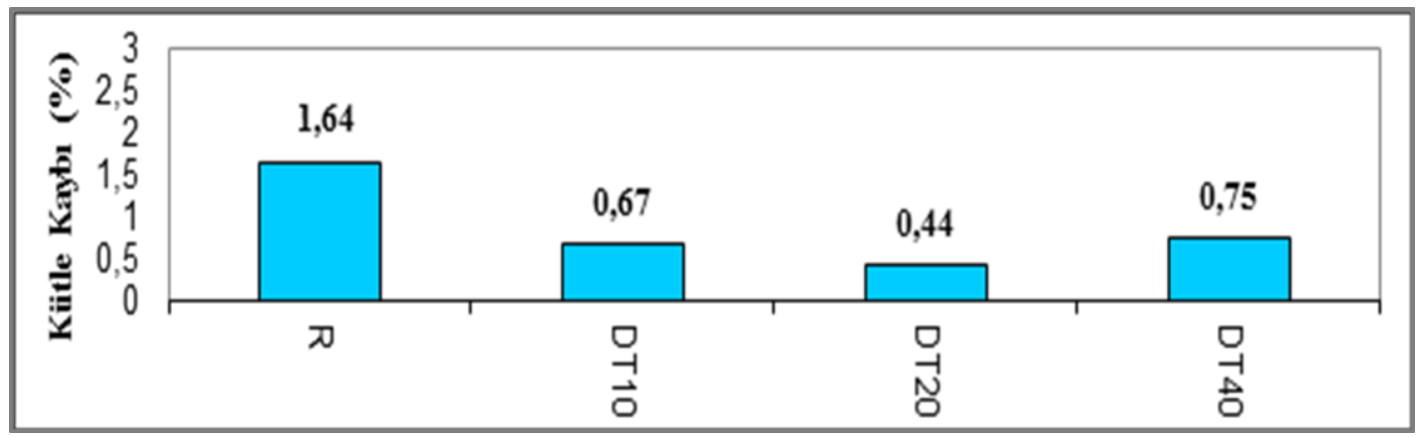

Şekil 17. Tuz çözeltisinde bekletilen harç numunelerin kütle kayıpları

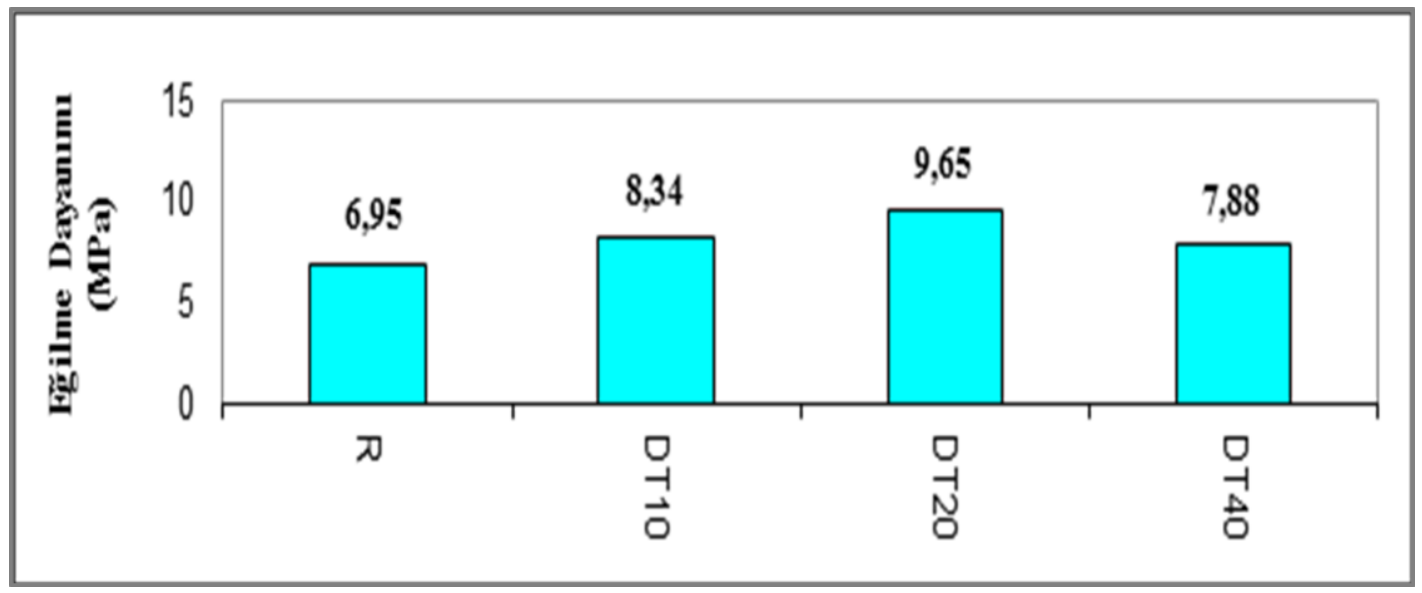

Şekil 18. Tuz çözeltisinde bekletilen harç numunelerin eğilme dayanımları

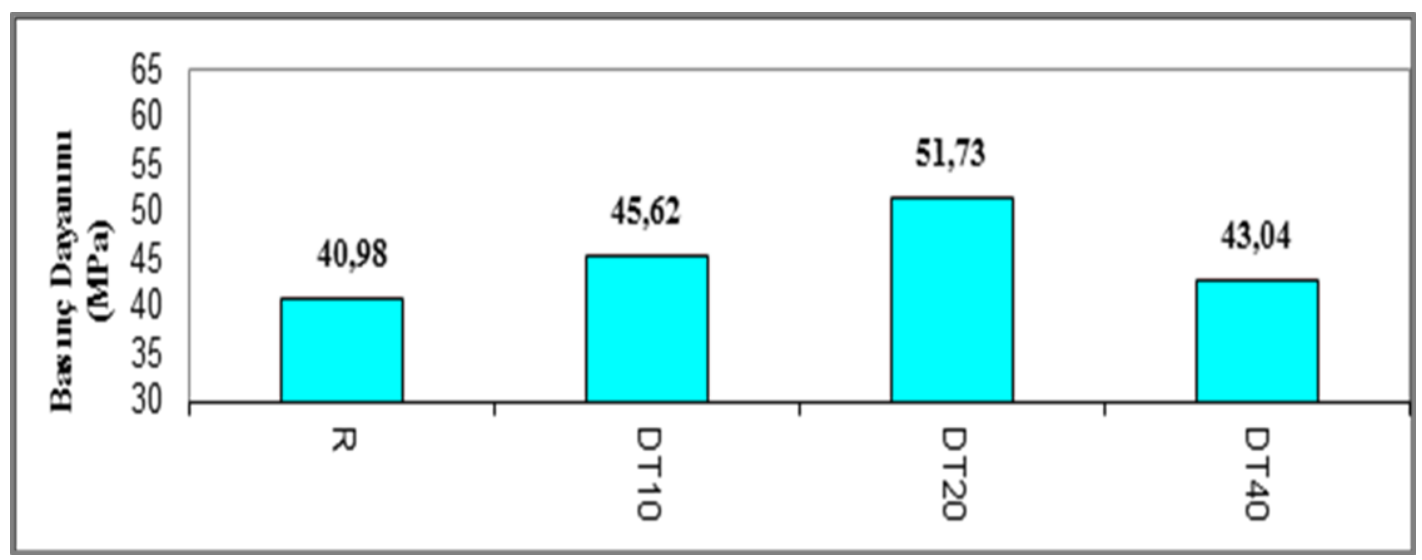

Şekil 19. Tuz çözeltisinde bekletilen harç numunelerin basınç dayanımları 
beton numuneler üçer adet, $71 \times 71 \times 71 \mathrm{~mm}$ ebatlarındaki örnekler kür tankında 28 günü tamamladıktan sonra, yüzey aşınma deneyine tabi tutulmuşlardır. Şekil 20'de numunelerin aşınma kayıları verilmiştir. Numunelerin aşınma kayıpları incelendiğinde (Şekil 20) tüm katkılı örneklerin referans numunesinden daha fazla dayanım gösterdiği görülmüştür. Bunun sebebi olarak atık demir tozunun sahip olduğu daha dayanıklı yapı ve yüzey sertliğinin betonun aşınma dayanımına olumlu katkı sağlaması şeklinde açıklanabilir. DT20 numunesinin aşınma değerinin demir tozu katkılı diğer numunelere oranla daha iyi çıkmasının nedeni olarak da basınç dayanımının yüksek olmasıyla paralel olarak boşluk oranının daha düşük olmasıyla açıklanabilir.

\subsection{Kılcal Su Emme Deneyi Sonuçları}

Kılcal su emme deneyi sonuçlarına ait absorbe edilen su miktarlarına bağlı kapilarite katsayıları Şekil 21'de her bir numune için ayrı ayrı kılcal su emme katsayısı-zaman grafiği görülmektedir.

Kilcal su emme deneyi yapilan numuneler ilk 60 dakika içerisinde yükselen bir kapilarite katsayısı grafiği çizmişlerdir. 60. dakikadan sonra su emme devam etmiştir. Ancak bu süreye kadar olan hızını kaybetmesi sebebiyle kapilarite katsayısı giderek düşmüştür. Yapılan deney ve hesaplamalar sonucunda tüm numunelerin benzer bir grafiğe sahip olduğu görülmektedir.

Referans numunesi tüm ölçümlerde en yüksek kapilarite katsayısına sahip olan numune olmuştur. İlk ölçümün alındığı 5 . dakika'da $2,382\left(\mathrm{~cm} / \mathrm{s}^{1 / 2}\right) \times 10^{-6}$ değerini vermiştir. En düşük kapilarite katsayısına sahip olan DT20 numunesi ise ilk ölçümde $1,233\left(\mathrm{~cm} / \mathrm{s}^{1 / 2}\right) \times 10^{-6}$ değerini vermiştir.

Numuneler grafiğin pik noktasına ulaştığı 60. dakika'da sirasiyla $3,470,2,187,1,870$ ve $2,252\left(\mathrm{~cm} / \mathrm{s}^{1 / 2}\right) \times 10^{-6}$ değerlerini vermişlerdir. Deneyin sona erdiği 1440. dakika'da ise $\mathrm{R}$ numunesi 0,873 ve DT20 numunesi $0,623\left(\mathrm{~cm} / \mathrm{s}^{1 / 2}\right) \times 10^{-6}$ değerini vermişlerdir.

\section{SONUÇLAR VE ÖNERİLER}

Çalışmada aşağıdaki sonuçlar elde edilmiştir.

1-) 7, 28, 60 ve 90 günlük beton numunelerde en yüksek basınç dayanımı değerini $\% 20$ oranında demir tozu katkılı numune, en düşük basınç dayanımı değerini referans numunesi vermiştir.

2-) 7, 28, 60 ve 90 günlük harç numunelerde en yüksek eğilme dayanımı değerini $\% 20$ oranında demir tozu katkılı numune, en düşük eğilme dayanımı değerini referans numunesi vermiştir.

3-) 7, 28, 60 ve 90 günlük harç numunelerde en yüksek basınç dayanımı değerini $\% 20$ oranında demir tozu katkılı numune, en düşük basınç dayanımı değerini referans numunesi vermiştir.

4-) 7, 28, 60 ve 90 günlük beton numunelerde ultrasonik ses cihazı kullanılarak tahribatsız yöntemlerle bulunan basınç dayanımı değeri deneysel olarak bulunan basınç dayanımı değerleri ile karşılaştırılmıştır. Ultrasonik ses cihazı kullanılarak tahribatsız yöntemlerle bulunan basınç dayanımı değerleri deneysel olarak bulunan basınç dayanımı değerlerine paralel çıkmıştır.

5-) 60 gün sülfat çözeltisinde bekletilen beton numunelerden elde edilen sonuçlara göre Demir Tozu katkılı numunelerin referans numunesine oranla basınç dayanımı artışı daha yüksek oranda gerçekleşmiştir. Sülfat çözeltisinde en fazla kütle kayb1 referans numunesinde ve en az kütle kaybı $\% 20$ oranında Demir Tozu katkılı numunede olmuştur.

6-) 60 gün tuz çözeltisinde bekletilen beton numunelerden elde edilen sonuçlara göre referans numunesinde demir tozu katkılı numunelere oranla basınç dayanımı kaybı daha yüksek oranda gerçekleşmiştir. Tuz çözeltisinde en fazla kütle kayb1 referans numunesinde ve en az kütle kayb1 $\% 20$ oranında Demir Tozu katkılı numune olmuştur.

7-) 60 gün sülfat çözeltisinde bekletilen harç numunelerden elde edilen sonuçlara göre Demir 


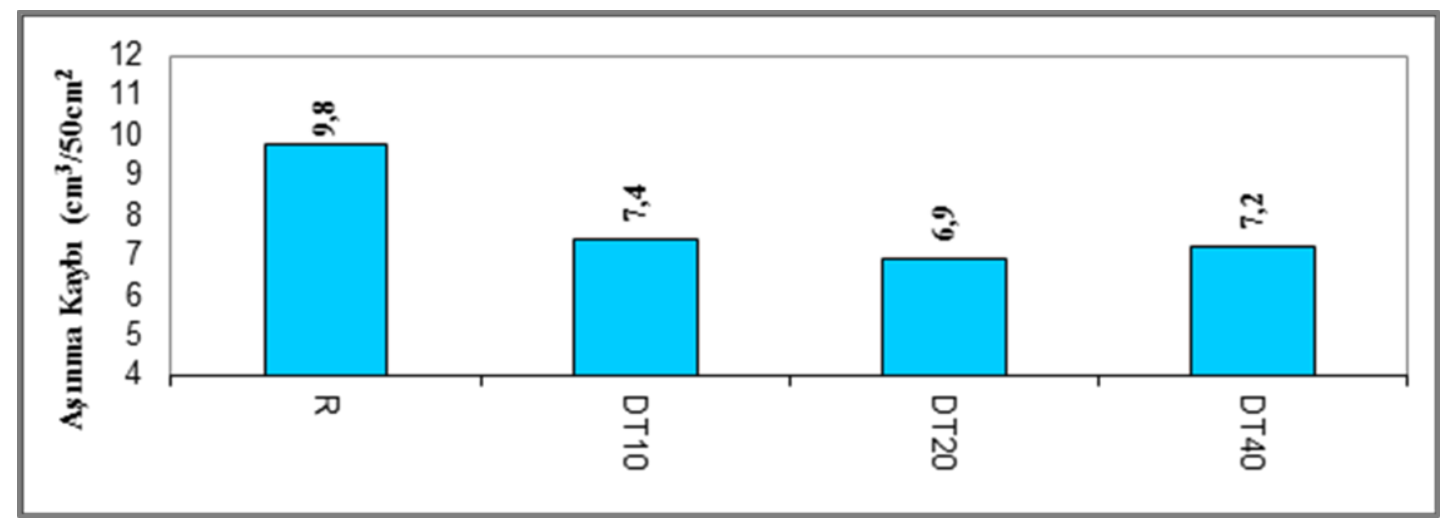

Şekil 20. 28 günlük beton numunelerin aşınma kayıpları

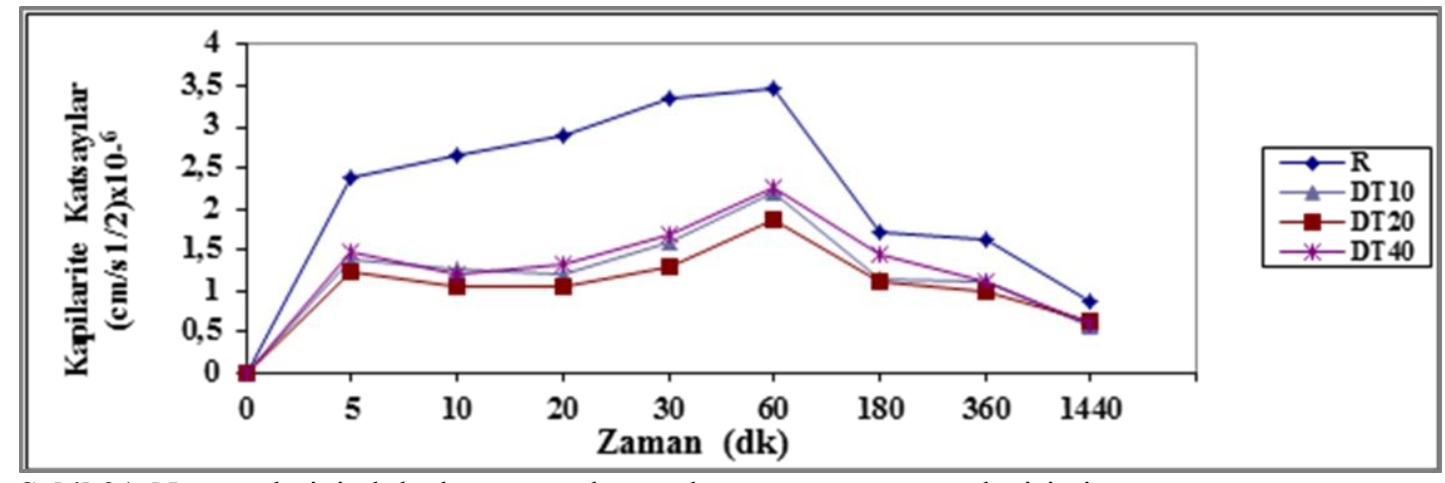

Şekil 21. Numunelerinin kılcal su emme katsayılarının zamana göre değişimi

Tozu katkılı numunelerin referans numunesine oranla basınç dayanımı ve eğilme dayanımı artışı daha yüksek oranda gerçekleşmiştir. Sülfat çözeltisinde en fazla kütle kaybı referans numunesinde ve en az kütle kaybı \%20 oranında demir tozu katkılı numunede olmuştur.

8-) 60 gün tuz çözeltisinde bekletilen harç numunelerden elde edilen sonuçlara göre referans numunesinde demir tozu katkılı numunelere oranla basınç dayanımı ve eğilme dayanımı kaybı daha yüksek oranda gerçekleşmiştir. Tuz çözeltisinde en fazla kütle kayb1 referans numunesinde ve en az kütle kaybı \%20 oranında Demir Tozu katkılı numune olmuştur.

9-) 28 gün'lük beton numunelerden en yüksek aşınma dayanımı değerini \%20 oranında Atık
Demir Tozu katkılı numune ve en düşük aşınma dayanımı değerini referans numunesi vermiştir.

10-) Referans numunesi en yüksek kılcal su emme değerine sahipken \% 20 DT katkılı örnek en düşük k1lcal su emme değerini vermiştir. Bu durumda söz konusu DT su emme oranı düşük beton üretimi için kullanılabilir. Özellikle betonun korozyona karşı korunmasına katkı sağlayabilir.

Yapılan çalışmada atık demir tozu atıklarla üretilecek beton ve harçlarda, referans betona göre daha üstün teknolojik özelliklere olduğu görülmüştür. Demir tozu atıkların harca katılmasıyla daha az girdi kullanıldığı için ekonomik beton elde edilebilir. Ayrıca bu durum ekolojik çevreninin korunmasına katkı sağlayacaktır. Üretilecek demir tozu katkılı beton 
ile geleneksel betonun maruz kaldığı basınç, aşınma, rötre, kimyasal etkiler gibi durabilite sorunlarını minimize edecektir.

\section{KAYNAKLAR}

1. Alparslan, B., Gültekin, A. B., Dikmen, Ç. B., 2009. Ekolojik Yapı Tasarım Ölçütlerinin Türkiye'deki Güneş Evleri Kapsamında İncelenmesi. 5. Uluslararası İleri Teknolojiler Sempozyumu, Karabük-Türkiye.

2. Esin, T., Yüksek, İ., 2009. Çevre Dostu Ekolojik Yapılar. 5. Uluslararası İleri Teknolojiler Sempozyumu, Karabük-Türkiye.

3. Hawken P., 1994. Waste. John Wiley and Sons, New York

4. Ismail Z. Z., Al-Hashmi E. A., 2008. Reuse of Waste Iron as a Partial Replacement of Sand in Concrete. Waste Manage 28, 2048-2053.

5. Soroushian P., Mirza F., Alhozaimy A., 1995. Permeability Characteristics of Polypropylene Fiber Reinforced Concrete. ACI Materials Journal. 92, 291-295.

6. Mannan MA, Ganapathy C., 2004. Concrete from an Agricultural Waste-oil Palm Shell (OPS). Build Environ, 39:441-8.

7. Qasrawi H., Shalabi F., 2009. Asi I. Use of Low $\mathrm{CaO}$ Unprocessed Steel Slag in Concrete as Fine Aggregate. Constr Build Mater. 23, 11181125 .

8. Taş H. H., Çoban Ö., Topbaşlı B., 2013. Endüstriyel Demir Talaş1 Atığının Betonun Bazı Mekanik Özelliklerine Etkisi. SDU International Technologic Science Vol. 5, 1-11. 